\title{
Efficacy of low-pressure foam cleaning compared to conventional cleaning methods in the removal of bacteria from surfaces associated with convenience food
}

\author{
Lambrechts A.A ${ }^{1}$, *Human I.S ${ }^{1}$, Doughari J.H¹, Lues J.F.R. ${ }^{2}$
}

1. Faculty of Applied Sciences, Cape Peninsula University of Technology, Cape Town, South Africa

2. Department of Life Sciences, Central University of Technology, Bloemfontein, South Africa

\begin{abstract}
Background: Food borne illnesses and food poisoning are cause for concern globally. The diseases are often caused by food contamination with pathogenic bacteria due largely to poor sanitary habits or storage conditions.

Objectives: Prevalence of some bacteria on cleaned and sanitised food contact surfaces from eight convenience food plants in Gauteng (South Africa) was investigated with the view to evaluate the efficacy of the cleaning methods used with such food contact surfaces.

Methods: The microbial load of eight convenience food manufacturing plants was determined by sampling stainless steel food contact surfaces after they had been cleaned and sanitised at the end of a day's shift. Samples were analysed for Total Plate Count (TPC), Escherichia coli, Salmonella species, Staphylococcus aureus and Listeria species.

Results: Results showed that $59 \%$ of the total areas sampled for TPC failed to comply with the legal requirements for surfaces, according to the Foodstuffs, Cosmetics and Disinfectants Act $\left(<100{\mathrm{cfu} . \mathrm{cm}^{-2}}^{-2}\right.$. S. aureus and Salmonella were not detected, but Listeria was detected in $23 \%$ and E. coli in $1.3 \%$ of the samples. Fifty percent (50\%) of the plants applied conventional cleaning methods for cleaning and sanitation and $50 \%$ used the low-pressure foam (LPF) method. There was significant difference $(P \leq 0.05)$ between the mean TPC values of the conventional cleaning method (14 358.82) compared to that of LPF method (2 386.51) but no significant difference $(P>0.05)$ in terms of Listeria species isolates obtained from both cleaning methods. The LPF method proved to be the superior cleaning option for lowering TPC counts.

Conclusion: Regardless of cleaning method used, pathogens continued to flourish on various surfaces, including dry stainless steel, posing a contamination hazard for a considerable period depending on the contamination level and type of pathogen. Intensive training for proper chemical usage and strict procedural compliance among workers for efficient cleaning procedures is recommended.
\end{abstract}

Key words: Disinfectants, food, Listeria spp., sanitation, Total plate count

DOI:http://dx.doi.org/10.4314/ahs.v14i3.13

\section{Introduction}

Public health concerns with food safety and food poisoning emerged in Britain in the 1880s, following the first indication that acute gastric illness was caused by a specific organism. ${ }^{38}$ The word 'sanitation' is derived from the Latin word 'sanitas', which refers to health. In the food industry, this means the application of a regime to provide safe, wholesome food processed in a clean environment by healthy workers who pose a limited health threat to the end-consumer. The South African

\section{*Corresponding author: \\ Human I.S \\ Faculty of Applied Sciences, \\ Cape Peninsula University \\ of Technology, Cape Town, \\ South Africa \\ humani@cput.ac.za}

food industry is changing rapidly and ready-to-eat products (convenience foods) internationally are becoming more popular. ${ }^{18}$ According to Brand, " $\mathrm{Tt}$ is confirmed that there is a significant growth in the convenience food market." This is due to the fact that the continuously fluctuating South African economy and the ever-increasing cost of living, has resulted in more people now working than ever before in order to survive as well as to sustain the average household income. Consequently, because of work pressure people seem to have less time to cook, thereby increasing the patronage of food convenience stores. Therefore, the need to assess the safety of food is increasingly being recognised. ${ }^{35}$ Unfortunately the attitude and/ or knowledge required to practice effective hygiene control is inadequate or even lacking in some food businesses. The bacteria responsible for food poisoning can proliferate quickly in food, especially in warm and moist conditions. A single bacterial cell on an item of food left out of the fridge overnight could produce 
millions of bacteria by the morning - sufficient to cause foodborne illness. ${ }^{39}$

A recent study conducted in restaurants determined the incidence of a number of significant foodborne pathogens and the general hygiene status, as estimated by TPCs and total coliform counts (TCCs), on the interior surfaces of domestic refrigerators. ${ }^{25}$ Some of the microbial isolates were found to survive and grow while refrigerated or under mild temperature abuse conditions. Such pathogens (pschycrophiles) may transfer to food in domestic fridges and multiply until they reach clinically significant numbers. ${ }^{19}$ These risks are of particular concerns in relation to 'ready-to-eat' foods, which will not receive any further processing before consumption. ${ }^{25} \mathrm{~A}$ study by Chao et al. ${ }^{10}$ revealed that counts of Listeria were $13.4 \%$ higher on delicatessen foods than on cooked foods investigated during their study. Moreover, non-spore-forming bacteria might be able to withstand dry conditions on surfaces for an extensive period. ${ }^{31}$ Surveillance of bacteria has also become increasingly important due to the increase in international food trade. ${ }^{36}$ In addition, microbiological hazards could stem from the introduction of new techniques for mass production as well as the rapidly growing, widespread distribution of foodstuffs. ${ }^{1}$

Organisms such as Total Aerobic Mesophiles, E. coli, S. aureus, Listeria species and Salmonella species normally isolated from meat, dairy and vegetable products have been universally utilised as indicators to determine the level of contamination on contactsurfaces after they have been cleaned and sanitised. ${ }^{5}$ Though the South African legal limit ${ }^{42,44}$ for TPC on food contact surfaces is $<100$ cfu.cm ${ }^{-2}$, current legislation does not make provision for maximum counts related to E. coli, S. aureus, Listeria species or Salmonella species on food contact surfaces. E. coli is not considered a serious foodborne hazard in countries with high sanitary standards and practices. Water contaminated with human sewage may lead to contamination of foods, as can handling by infected food handlers resulting in the infrequent isolation of these organisms from such food products. ${ }^{27}$

$S$. aureus food poisoning usually occurs rapidly and is in many cases acute, depending on the individual's susceptibility to the toxin produced by this microbe, the amount of contaminated food eaten, the amount of toxin in the food ingested and the general health of the victim. ${ }^{27}$ Staphylococci exist in air, dust, sewage, water, milk and food or on food equipment, environmental surfaces, humans and animals. Humans and animals are the primary reservoirs of the bacteria, ${ }^{27}$ which are present in the nasal passages and throats and on the hair and skin of over $50 \%$ of healthy individuals. Although food handlers are usually the main source of food contamination in food poisoning outbreaks, equipment and environmental surfaces can also be sources of contamination. ${ }^{27}$

Salmonella food poisoning appears to be rising in the United States as well as in other industrialised nations. ${ }^{4}$ Salmonella enteritidis isolations from humans have risen dramatically in the past decade, particularly in the Northeast USA (sixfold or more), and the increase in human infections is spreading south and west, with sporadic outbreaks occurring in other regions. ${ }^{8}$ Salmonella inhabit the intestinal tracts of humans and other animals, including birds, and in any raw food of animal origin, such as meat, poultry, milk and dairy products, eggs, seafood and on some fruits and vegetables. ${ }^{27}$

The aim of this study was to identify whether selected organisms are present on cleaned and sanitised food contact surfaces from eight convenience food plants in Gauteng (South Africa), to relate the bacterial count to the legal limit and to compare and evaluate the cleaning methods used with such food contact surfaces.

\section{Materials and methods Sampling protocol}

This study was conducted among a sample of convenience food manufacturers supplying convenience food products (ready-to-eat lunch foods) to retail outlets in the Gauteng area of South Africa. Eight outlets (amounting to $20 \%$ of the medium to large manufacturing plants that supply the retail industry in the region) were chosen because they mainly focus on preparing ready-to-eat lunch meals. Foods manufactured included ready-to-eat salads, sandwiches, fruit salads, filled pancakes or omelettes and cocktail burgers. The management staff at each of the manufacturing plants sampled, granted permission to conduct the survey and subsequent interviews. None of the premises were Hazard Analysis Critical Control Point (HACCP) certified. The various food manufacturers used different chemical suppliers and the chemical companies had different levels of cleaning technology, therefore, different levels of cleaning methods were applied. ${ }^{47}$

Fifty percent of the outlets used traditional methods such as manual cleaning (brush and bucket) and were supplied by local chemical manufacturers. The brush and bucket method refers to physical energy being carried out by people, using pressure and movement 
on surfaces. A brush with hot water and detergent are used for cleaning. Sufficient contact time is allowed to disinfect the surfaces with chemicals. Thereafter the chemical residue is removed by a final rinse and the surfaces are allowed to air dry. International companies supplied the remainder of the plants and they used more modern technologies (for instance, low-pressure foam cleaning systems). Low-pressure foam cleaning involves a mechanized system of low pressure in combination with specialized foam detergents and disinfectants in the following steps - pre-wash, application of foam detergent, exposure, rinsing, disinfecting and final finishing wash.

Stainless steel food contact surfaces at the manufacturing plants were sampled by means of swabs after they had been cleaned and sanitised at the end of each day's shift. ${ }^{43}$ The samples were collected in accordance with local health legislation. ${ }^{42}$ To ensure that the usual level of cleaning applied to contact surfaces occurred in all of the manufacturing plants, workers were not informed of the planned sample collection. The sampling was performed on days that required no overtime work, as overtime would potentially decrease the time allocated for cleaning the contact surfaces. Thus, adequate time was available for cleaning and sanitising of all contact surfaces. All samples were analysed on the same day. A total of 477 microbiological samples (Table 1) were collected according to the SABS swab technique ${ }^{40}$ and all analyses were performed at least twice.

Table 1. Total plate count (TPC) and bacterial content of samples collected from cleaned and sanitised convenience food contact surfaces at eight food manufacturing plants.

\begin{tabular}{|c|c|c|c|c|c|c|}
\hline $\begin{array}{c}\text { Food } \\
\text { Manufacturing } \\
\text { Plants }\end{array}$ & ${ }^{1}$ TPC & $\begin{array}{c}{ }^{2} \text { Salmonella } \\
\text { species }\end{array}$ & $\begin{array}{c}{ }^{3} \text { Listeria } \\
\text { species }\end{array}$ & $\begin{array}{c}{ }^{4} \text { Staphylococcus } \\
\text { aureus }\end{array}$ & $\begin{array}{c}{ }^{5} \text { Escherichia } \\
\text { coli }\end{array}$ & $\begin{array}{c}\text { Total/ } \\
\text { plant }\end{array}$ \\
\hline 1 & 25 & 3 & 17 & 3 & 10 & 58 \\
\hline 2 & 41 & 5 & 27 & 5 & 13 & 91 \\
\hline 3 & 21 & 3 & 14 & 3 & 8 & 49 \\
\hline 4 & 30 & 4 & 20 & 4 & 12 & 70 \\
\hline 5 & 14 & 3 & 10 & 3 & 7 & 37 \\
\hline 6 & 23 & 3 & 16 & 3 & 9 & 54 \\
\hline 7 & 32 & 4 & 21 & 4 & 11 & 72 \\
\hline 8 & 19 & 2 & 14 & 2 & 9 & 46 \\
\hline Total & 205 & 27 & 139 & 27 & 79 & 477 \\
\hline
\end{tabular}

\section{Microbiological analysis}

The TPC samples were analysed using the conventional pour plate technique specified in ISO Method 4833 (International Organisation for Standardization, 2003). To isolate other bacteria, the samples were first enriched using a non-selective enrichment broth (NSEB) and incubated at $35-37^{\circ} \mathrm{C}$ for $16-18 \mathrm{~h}$. To isolate E. coli, solid growth media as stipulated in ISO Method 16649-2 ${ }^{24}$ was used. $S$. aureus was isolated using the spread plate technique by spread inoculating $(0.1 \mathrm{ml})$ of the culture broth from NSEB onto the surface of a dried prepoured Baird-Parker agar (BPA) medium in a Petri-dish and incubating at $37^{\circ} \mathrm{C}$ for $24 \mathrm{~h}$. Coagulase production among $S$. aureus isolates was determined using ISO Method 6888-1. ${ }^{22}$ Listeria species were isolated culturing the NSEB broth culture onto solid media using the conventional technique described in ISO 112901. ${ }^{21}$ Similarly Salmonella species were also isolated by culturing the NSEB culture onto solid media using the Malthus's method. ${ }^{21,40}$ All bacteria were characterized using morphological and biochemical characteristics before serological confirmation. Presumptive positive colonies were confirmed using latex agglutination kits as follows: Salmonella latex kit (SWJM 42) (Swift Micro Laboratories) for Salmonella spp., ${ }^{48}$ Latext agglutination 
test kit (Hardy Diagnostics) for E. coli, Staph latex kit (Remel) for S. aureus and DR1126 Listeria test kit (Oxoid) for Listeria spp. ${ }^{48}$

\section{Data analysis}

The results were analysed with assistance from Corrie Uys, statistician at the Cape Peninsula University of Technology's Centre for Postgraduate Studies and were presented as frequencies and percentages in tables and graphs.

\section{Results and Discussion}

Microbiological results for convenience food contact surfaces

\section{Total Plate Count}

The sample size (205 samples) proved to be $95 \%$ accurate as a representative sample of the population when using the Confidence and Error method with a tolerance of $5 \%$. Plant 1 showed the highest TPC values of $2.07 \times 10^{5} \mathrm{cfu}_{\mathrm{cm}} \mathrm{cm}^{-2}$. Although all plants sampled had areas where there was no bacterial growth, all exceeded the legal limit of $<100 \mathrm{cfu}_{\mathrm{cm}} \mathrm{cm}^{-2}$ average TPC (Figure 1).

Figure 1. Comparison between the Total Plate Count (TPC) average and the standard deviation versus the legal limit of $<100$ cfu.cm ${ }^{-2}$ across manufacturing plants

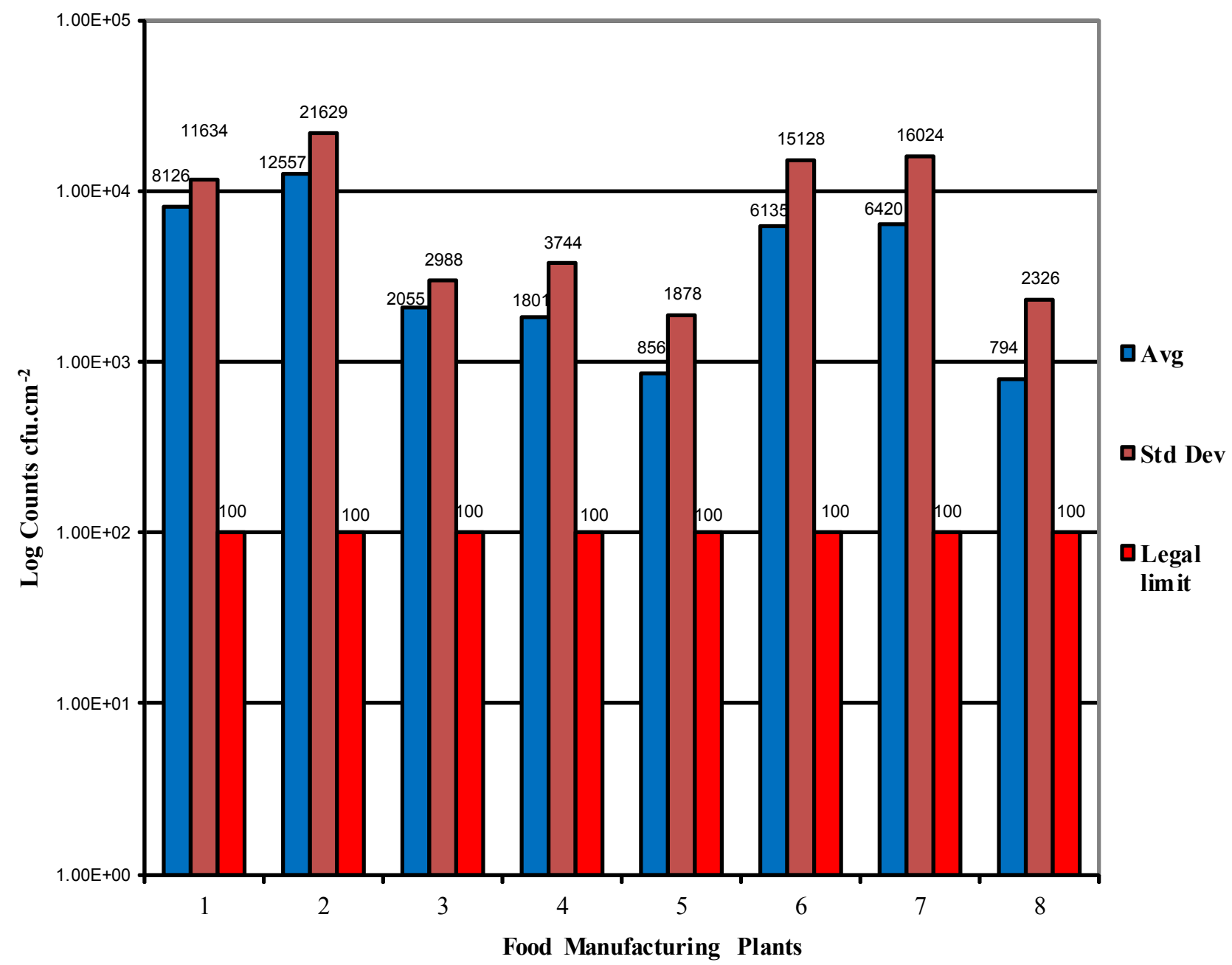

Results also showed that the average bacterial count and normal data distribution or standard deviation also considerably exceeded the legal limit. This may indicate insufficient cleaning and disinfection, since effective cleaning processes should yield a significantly reduced or zero TPC. ${ }^{30,47}$
Table 2 presents a summary of the total samples taken and shows the compliance with the legal limit $(<100$ cfu.cm ${ }^{-2}$ for TPC). ${ }^{43}$ Overall, 84 of the 205 TPC samples (41\%) complied with the legal requirement, whereas 121 of the 205 samples (59\%) did not comply. 
Escherichia coli, Staphylococcus aureus, Salmonella species and Listeria species
Table 2 shows the total samples investigated for the presence or absence of E. coli, S. aureus, Salmonella species and Listeria species.

Table 2. Compliance with the legal limit $\left(<100 \mathrm{cfu} . \mathrm{cm}^{-2}\right.$ for TPC) and the prevalence of bacteria on the cleaned and sanitised convenience food contact surfaces in the eight food manufacturing plants

\begin{tabular}{|c|c|c|c|c|c|c|c|}
\hline \multirow{2}{*}{ Test } & \multirow{2}{*}{$\begin{array}{c}\text { No. of samples } \\
\text { (n) }\end{array}$} & \multicolumn{3}{|c|}{ COMPLIANCE } & \multicolumn{3}{|c|}{ NON-COMPLIANCE } \\
\hline & & Absent & $\begin{array}{l}\text { 0-100 cfu. } \\
\mathrm{cm}^{-2}\end{array}$ & $\%$ & Present & $\begin{array}{l}>100 \mathrm{cfu} \\
\mathrm{cm}^{-2}\end{array}$ & $\%$ \\
\hline TPC & 205 & & 84 & 41 & & 121 & 59 \\
\hline Eschericbia coli & 80 & 79 & & 98.7 & 1 & & 1.3 \\
\hline $\begin{array}{l}\text { Staphyllococcus } \\
\text { aureus }\end{array}$ & 27 & 27 & & 100 & $\mathrm{~N} / \mathrm{O}$ & & 0 \\
\hline Salmonella species & 27 & 27 & & 100 & $\mathrm{~N} / \mathrm{O}$ & & 0 \\
\hline Listeria species & 139 & 107 & & 77 & 32 & & 23 \\
\hline
\end{tabular}

$\mathrm{N} / \mathrm{O}=$ not observed

Results showed that $1.3 \%$ of the samples investigated yielded E. coli isolates. Although S. aureus and Salmonella species were absent on these surfaces, $23 \%$ of all the samples yielded Listeria species. These pathogens pose a considerable threat to the safety of convenience food consumers. ${ }^{29}$ Listeria species especially $L$. monocytogenes are of great concern to retailers in South Africa. The presence of this organism immediately is a reason for concern and the retailer's procurement divisions will act strongly against any supplier who supplies products that indicate the presence of Listeria species. ${ }^{3,32}$ The organism is associated with listeriosis, which can be life threatening and causes septicaemia, meningitis and even stillbirth in high-risk populations. ${ }^{29}$ Factory environments are not sterile and $L$. monocytogenes can be found anywhere in the natural environment. ${ }^{46}$ The bacteria are easily introduced into food production and processing facilities through many routes and may establish colonies on food processing equipment. They also have the properties needed to survive refrigeration temperatures and resist freezing. ${ }^{20,33}$ Based on recent estimates from the Centres for Disease Control and Prevention of the United States, the annual incidence of death caused by listeriosis is about eight times greater than the mortality due to E. coli $\mathrm{O} 157: \mathrm{H} 7$ infections. ${ }^{37}$

Many commonly used disinfecting or sanitising agents, such as quaternary ammonium compounds, chlorine and iodophors have been shown to be effective against Listeria species in suspension, but organic material reduces the activity of disinfectants. ${ }^{46}$ Subsequently, food products may become contaminated during processing. L. monocytogenes may grow in biofilms that protect them against environmental stress and can be isolated from surfaces after they have been cleaned and disinfected. They can also adhere to all of the materials commonly used in the food industry. In many food processing environments, the slow flowing water rich in supplies of nutrient suspensions provide conditions that favour bacterial adherence. ${ }^{6}$ Therefore, several challenges including their increased resistance to sanitisers and their ability to grow at the low temperatures found in 
ready-to-eat processing plants - exist in controlling the proliferation of $L$. monocytogenes.

Although there are limited specifications available on bacteria in food in South Africa, the norm is that all pathogens should be absent. ${ }^{42}$ Listeria species are very common and can be found almost anywhere in the environment. As such, with food processing and manufacturing, there is the potential to introduce the organism continuously. ${ }^{12}$ The challenge is to direct efforts to prevent the growth and establishment of Listeria within the plant through having appropriate controls such as sanitation, proper manufacturing practices and employee training. ${ }^{17}$

E. coli was found on one sample in Plant 1 only, whereas the most positive Listeria samples were found in Plants 1 and 7. Plant 1 also showed the highest average bacterial count, followed by Plant 7. It appears that the overall hygiene standard of the plant influences the presence of Listeria.

\section{Statistical comparisons of cleaning methods}

Statistical analyses were used to determine which cleaning method (conventional cleaning methods or lowpressure foam cleaning) is most suitable for application in the convenience food industry. And to conclusively demonstrate the efficacies of the cleaning methods, SABS 1853 approved sanitisers ${ }^{45}$ that kill $99.9 \%$ of microorganisms were used in 7 out of the 8 plants. The expected outcome was that all samples should be close to zero or at least comply with the legal requirements of $<100$ cfu. $\mathrm{cm}^{-2}$. The samples were taken from identical surfaces to ensure uniform results. Results indicated that the LPF system is more effective, as proved by the lower mean of the TPC found on convenience food contact surfaces in which this method was employed for cleaning purposes (Table 3). A statistical significant difference $(P \leq 0.05)$ was found in the TPC means of the cleaning methods (Table 3). The LPF method consistently proved to be the better cleaning option for reducing TPCs. The presence of Listeria species on convenience food contact surfaces was statistically evaluated with no significant difference $(P=0.812)$ found between the cleaning methods used. ${ }^{26}$

Table 3. Statistical comparison of of Total Plate Count (CPC) values of conventional cleaning and low-pressure foam cleaning methods used on convenience food contact surfaces at eight food manufacturing plants

\begin{tabular}{|c|c|c|c|c|c|c|}
\hline & Plants & $\mathbf{N}=\mathbf{2 0 5}$ & $\begin{array}{c}\text { Mean } \\
\text { TPC }\end{array}$ & $\begin{array}{c}\text { Median } \\
\text { TPC }\end{array}$ & $\begin{array}{c}\text { Standard } \\
\text { deviation }\end{array}$ & $\begin{array}{c}\text { *P-value } \\
\text { cleaning } \\
\text { methods }\end{array}$ \\
\hline $\begin{array}{c}\text { Conventional } \\
\text { method }\end{array}$ & $1,2,3,7$ & 119 & 14358.82 & 1240.00 & 33560.897 & \\
\hline LPF method & $4,5,6,8$ & 86 & 2386.51 & 35.00 & 7201.980 & $\mathbf{P} \leq \mathbf{0 . 0 5}$ \\
\hline
\end{tabular}

$* P$-values were calculated between the cleaning methods

\section{Conclusion}

The results highlighted the presence of high counts of bacteria, including Listeria spp that was detected on the sanitised or disinfected convenience food contact surfaces. Fifty-nine percent (59\%) of the TPC samples analysed exceeded the legal specification $(<100 \mathrm{cfu}$. $\mathrm{cm}^{-2}$ for food contact surfaces) when measured against the requirements of the Foodstuffs, Cosmetics and Disinfectants Act. ${ }^{28,43}$ It is alarming that these plants use reputable chemical suppliers' approved products but still exhibit a pathogen contamination as well as generally high bacterial counts on contact surfaces. The majority of positive samples for Listeria and TPC were found in Plants 1 and 7, with one sample in Plant 1 showing the presence of E. coli. Both of these plants made use of the conventional cleaning method.

The LPF method was found to be significantly better $(P \leq 0.05)$ than the conventional cleaning method in the manufacturing plants utilising these methods, respectively. Result of this study also raises the question as to whether workers or cleaners have sufficient knowledge and/or insufficient training on how to apply the chemicals correctly to achieve the desired results. It is therefore recommended that the management of 
the various plants consider the possibility of providing intensive training to the production workers and general cleaners. This study has further highlighted the fact that pathogens continue to flourish on various surfaces, including dry stainless steel, and present a contamination hazard for a considerable period, depending on the contamination level and type of pathogen. ${ }^{31}$

\section{References}

1. American Institute of Baking (AIB). AIB Consolidated Standards for Food Contact Packaging Manufacturing Facilities. 2002.

2. American Meat Institute's Fact sheet on microbiological testing. Food Safety and Inspection Service, Assessing the Effectiveness of the "Listeria monocytogenes" Interim Final Rule Report, Washington DC. 2004. Available from http://www.meatsafety.org (Accessed 30 November 2009).

3. Augustin, J-C. Evaluation of the sensitivity of microbiological criteria for Listeria monocytogenes in detecting unsafe food according to the prevalence of the pathogen and the shelf-life of the food. Food Microbiology. 2003; 20(6):681-689.

4. Arduser, L., Brown, R.B. HACCP \& Sanitation in Restaurants and Food Service Operations: A Practical Guide Based on the FDA Food Code. 2005; 34. Florida: Atlantic Publishing Group.

5. Beckwith, $\mathrm{T}$ Clean it or recall it, food plant sanitation manual, p. 1. Bloomington, Indiana. 2008.

6. Blackman, I.C. \& Frank, J.F. Growth of Listeria monocytogenes as a biofilm on various food-processing surfaces. Journal of Food Protection. 1996; 59: 827-831.

7. Brand, J. Personal communication from Shoprite/ Checkers. 2008.

8. Centers for Disease Control and Prevention. Morbidity and Mortality Weekly Report, 1995;44(49): 12531276. Available from http://www.cdc.gov/mmwr/index2005.htm.

9. Centers for Disease Control and Prevention. Morbidity and Mortality Weekly Report, 1996; 45(42): 901-936. Available from http://www.cdc.gov/mmwr/preview/index96.html. 10. Chao, G., Deng, Y., Zhou, X., Xu, Q., Qian, X., Zhou, L., Zhu, Binyang, Z. Prevalence of Listeria monocytogenes in delicatessen food products in China. Food Control. 2006; 17(12): 971-974.

11. Clive, D. Foodborne Diseases. $2^{\text {nd }}$ edition. Toronto: Academic Press. 2002.

12. Donnelly, W.C. Editorial: Dispelling Myths about Environmental Listeria Control Using Rapid, Cost-Effective Methods. 2002.
13. Elliot, T.R., Marth, E.H. Listeria, Listeriosis, and Food Safety. 3rd edition. United States: CRC Press Taylor \& Francis Group. 2007.

14. Garbutt, J.H., Garbutt, J. Essentials of Food Microbiology. London: Hodder Arnold. 1997.

15. Gough, N.L., Dodd, C.E.R. The survival and disinfection of Salmonella typhimurium on chopping board surfaces of wood and plastic. Food Control. 1998; 9(6): 363-368.

16. Gounadaki, A.S., Skandamis, P.N., Drosinos, E.H., Nychas, G-J.E. Microbial ecology of food contact surfaces and products of small-scale facilities producing traditional sausages. Food Microbiology Journal. 2008; 205: 313-323.

17. Gilbert, R.J., de Louvois, J., Donovan, T., Little, C., Nye, K., Ribeiro, C.D., Richards, J., Roberts, D., Bolton, F.J. Guidelines for the microbiological quality of some ready-to-eat foods sampled at the point of sale. Communicable Disease and Public Health. 2000; 3(3).

18. Guillermo, E. Principles of Cleaning and Sanitation in the Food and Beverage Industry. Nebraska: Universe. 2006.

19. Hayes, P.R., Forsythe, S.J. Food Hygiene Microbiology and HACCP. $3^{\text {rd }}$ edition. United States: Kluwer Academic/Plenum Publishers. 1989.

20. Hemminger, J.M. Food Safety: A Guide to What you Really Need to Know. Iowa: Iowa State University Press. 1999.

21. International Organisation for Standardization. ISO 11290-1: 1996 Microbiology of food and animal feeding stuffs -- Horizontal method for the detection and enumeration of Listeria monocytogenes -- Part 1: Detection method. 1996.

22. International Organisation for Standardization. ISO 6888-1:1999 Microbiology of food and animal feeding stuffs -- Horizontal method for the enumeration of coagulase-positive staphylococci (Staphylococcus aureus and other species) -- Part 1: Technique using Baird-Parker agar medium. 1999.

23. International Organisation for Standardization. ISO 16649-2:2001 Microbiology of food and animal feeding stuffs -- Horizontal method for the enumeration of beta-glucuronidasepositive Escherichia coli -- Part 2: Colony-count technique at 44 degrees $C$ using 5-bromo-4-chloro-3-indolyl beta-D-glucuronide. 2001.

24. International Organisation for Standardization. ISO 4833:2003 Microbiology of food and animal feeding stuffs -Horizontal method for the enumeration of microorganisms -Colony-count technique at 30 degrees C. 2003.

25.Jackson, V., Blair, I.S., McDowell, D.A., Kennedy, J., Bolton, D.J. The incidence of significant foodborne pathogens in domestic refrigerators. Food Control. 2007; 18(4): 346-351. 
26. Jankowicz, A.D. Business Research Projects. $3^{\text {rd }}$ edition. London: Thomson Learning. 2002.

27. Jay, J.M., Loessner, M.J., Golden, D.A. Modern Food Microbiology. $7^{\text {th }}$ edition. United States: Springer. 2005.

28. Keller, S.E., Merker, R.I., Taylor, K.T. Tan, H.L., Melvin, C.D., Christel, S.T., Miller, A.J. Efficacy of Sanitation and Cleaning Methods in a Small Apple Cider Mill. Journal of Food Protection. 2002; 65(6): 911-917.

29. Kornacki, J.L., Gurtler, J.B. Incidence and control of Listeria monocytogenes in food processing facilities. Chapter 17. Boca Raton, Florida: CRC Press Taylor \& Francis Group. 2007.

30. Krishnamurty, G.B., Kasovia-Schmitt, P., Ostroff, D.J. Statistics: An interactive text for the health and life sciences. London: Jones \& Bartlett Publishers. 1995.

31. Kusumaningrum, H.D., Riboldi, G., Hazelger, W.C., Beumer, R.R. Survival of foodborne pathogens on stainless steel surfaces and cross-contamination to foods. International Journal of Food Microbiology. 2003; 85(3): 227-236.

32. Loken, J.K. The HACCP Food Safety Manual. New York: John Wiley \& Sons Inc. 1995.

33. Lou, Y., Yousef, A.E. Adaptation to sub-lethal environmental stresses protects Listeria monocytogenes against lethal preservation factors. Applied and Environmental. Microbiology. 1997; 63(4): 1252-1255.

34. Marriott, N.G., Gravani, R.B. Principles of Food Sanitation. $5^{\text {th }}$ edition. United States: Springer. 2006;10: 190. 35. Mattick, K., Durham, K., Domingue, G., Jorgensen, F., Sen, M., Schaffner, D.W., Humphrey, T. The survival of foodborne pathogens during domestic washingup and subsequent transfer onto washing-up sponges, kitchen surfaces and food. International Journal of Food Microbiology. 2003; 85(3): 213-226.

36. Mayes, T., Mortimore, S. Making the most of HACCP. Cambridge: Woodhead Publishing Limited. 2001.

37. Mead, P.S., Slutsker, L., Dietz, V., McCaig, L.F., Bresee, J.S., Shapiro, C., Griffin, P.M., Tauxe, R.V. Food related illness and death in the United States. Emerging Infectious Diseases. 1999; 5: 607-625.

38. Morabia, A., Hardy, A. The pioneering use of a questionnaire to investigate a foodborne disease outbreak in early 20th Century Britain. Journal of Epidemiology \& Community Health. 2005; 59: 94-99.

39. Prescott, L.M., Harley, J.P., Klein, D.A. Microbiology. $3^{\text {rd }}$ edition. . P. 886 Dubuque, Iowa: Wm. C. Brown Publishers. 1996.

40. Quinn, C. A comparison of conventional culture and three rapid methods for the detection of Salmonella in poultry feeds and environmental samples. Letters in Applied Microbiology. 1995; 20(2):89-91

41. Republic of South Africa. Health Act No. 63 of 1977. Pretoria: Government Printer. 1977.

42. logical Standards for Foodstuffs and Related Matters (R. 692 of 16 May 1997), Promulgated Under the Foodstuffs, Cosmetics and Disinfectants Act 54 of 1972. 1997. Pretoria: Government Printer.

43. Republic of South Africa. Regulation 962 of 2012: Regulations governing general hygiene requirements for food premises and the transport of food, promulgated under the Foodstuffs, Cosmetics and Disinfectants Act, No. 54 of 1972. 2012. Pretoria: Government Printer.

44. South African National Standards 1853: Disinfectants for use in the food industry. 2001.

45. South African Bureau of Standards. Swab technique method 762. 1975.

46. Van De Weyer, A., Devleeschouwer, M-J., Dony, J. Bactericidal activity of disinfectants on Listeria. Journal of Applied Bacteriology. 1993; 74: 480-483.

47. Verran, J., Boyd, R.D., Hall, K., West, R.H. Microbiological and Chemical Analyses of Stainless Steel and Ceramics Subjected to Repeated Soiling and Cleaning Treatments. Journal of Food Protection. 2001; 64(9): 13771387.

48. Swift Micro Laboratories Quality Manual - Method SWJM 42. 